\title{
Leptosynapta inhaerens (O.F. Müller 1776) (Echinodermata, Holothuroidea): A new record for the Belgian marine waters
}

\author{
Claude Massin ${ }^{1}$, Jan Wittoeck ${ }^{2}$ \& Kris Hostens ${ }^{2}$
}

\author{
1 Royal Belgian Institute of Natural Sciences (RBINS), Rue Vautier 29, 1000 Brussels, Belgium \\ 2 Institute for Agricultural and Fisheries Research (ILVO), Animal Sciences Unit - Aquatic Environment and Quality, \\ Ankerstraat 1, 8400 Oostende, Belgium \\ * Corresponding author: jan.wittoeck@ilvo.vlaanderen.be
}

\begin{abstract}
This is the first record of Leptosynapta inhaerens (O.F. Müller, 1776) in Belgian marine waters and adds a second apodid species, the first being Leptosynapta minuta (Becher, 1906), to the Belgian holothuroid fauna. This paper contains a morphological description of the specimens, the habitat characteristics, and includes a world distribution map of $L$. inhaerens. Relationships between $L$. inhaerens and environmental data are discussed.
\end{abstract}

KEY WORDS: Synaptidae, Leptosynapta, North Sea, new occurrence, distribution

\section{INTRODUCTION}

Belgian marine waters are, to date, known to harbour only six holothuroids: five Dendrochirotida: Aslia lefevrei (Barrois, 1882), Neopentadactyla mixta (Östergren, 1898) Deichmann, 1944, Ocnus lacteus (Forbes \& Goodsir, 1839), Ocnus planci (Brandt, 1835) \& Thyone fusus (O.F. Müller, 1776) (MASSIN, 1988; MASSIN \& DERIDDER, 1989; VANDEPITTE, 2010) and one Apodida: Leptosynapta minuta (Becher, 1906) (MASSIN et al., 2005). The current species was collected with a Van Veen grab by the Institute for Agricultural and Fisheries Research (ILVO) on sandy muddy bottoms close to the Buiten Ratel sandbank. Careful inspection of the specimen revealed that it represents a sixth holothuroid species in Belgian marine waters. This paper describes Leptosynapta inhaerens (O.F. Müller, 1776) as a new record of an apodid holothuroid species in Belgian marine waters.

\section{MATERIALS AND METHODS}

The sampling station (BRN10 2012/194/24702), where the first L. inhaerens was found, is situated in the northern part of the Buiten Ratel sandbank (coordinates: $51^{\circ} 18.79$ Lat $-2^{\circ} 36.52$ Long (WGS84)), in a zone where aggregate extraction takes place (Map 1: C1). The sample was taken on the $3^{\text {rd }}$ of October 2012 during an ILVO sampling campaign on board the oceanographic research vessel A962 BELGICA. Using a VAN VEEN grab (sampling surface area: $0.1 \mathrm{~m}^{2}$ ), a sediment sample was taken and rinsed through a $1 \mathrm{~mm}$ mesh sieve, after which the animals remaining were fixed with an $8 \%$ buffered formaldehyde-seawater solution. To determine the grain size distribution, a subsample of the sediment sample (2012/194/24765) was taken with a $3.6 \mathrm{~cm} \varnothing$ core prior to sieving. This sample was sieved in the laboratory through a $1.6 \mathrm{~mm}$ sieve to calculate the coarser sediment proportion. The rest of the sample was passed through a MALVERN Mastersizer, to determine the grain size distribution of the sand/silt fraction by means of laser diffraction.

The first specimen found was broken into two pieces. It was stained with eosin to facilitate sorting and preserved in alcohol (90\%) before transfer to the Royal Belgian Institute of Nature Sciences (RBINS). There the specimen was 
stored in buffered alcohol (70\%, $\mathrm{pH} 8.3)$ and registered under $\mathrm{N}^{\circ}$ IG 32529/1.

Recently, a second specimen (also in two pieces) was collected in sediment samples taken with a Hamon grab during a RBINS Belgica campaign (pers. comm. F. Kerckhof). The samples were taken on the $3^{\text {rd }}$ of July 2013 in the Westhinder area just west to the Oosthinder sand bank (coordinates: $51^{\circ} 24.75$ Lat $-2^{\circ} 31.61$ Long (WGS84)) in between barchan dunes (Map 1: C2). It is registered under $\mathrm{N}^{\circ}$ IG 32529/2 in the collections of the RBINS.

Tissue from the body wall, longitudinal muscles and one tentacle were prepared for detailed examination. To preserve the integrity of the specimen as much as possible, only 2 of the 12 tentacles were removed for preparation. For the same reason no dissection has been performed to observe the internal anatomy. The ossicles were mounted on slides according to the method of SAMYN et al. (2006).

\section{DESCRIPTION}

Order Apodida (Brandt, 1835)

Family Synaptidae (Burmeister, 1837)

Subfamily Leptosynaptinae (Smirnov, 1989)

Genus Leptosynapta (Verrill, 1867)

Leptosynapta inhaerens (O.F. Müller, 1776)

Figs 1A-B, 2A-E; Maps 1-2

Holothuria inhaerens (O.F. MÜLLER, 1776): 232; 1781: pl.31, figs 1-7.

Synapta inhaerens (von DÜBEN \& KOREN, 1844): 322: tab V, figs 56-62.

Leptosynapta inhaerens (VERRILL, 1867): 325.

(SoOK SHIN, 2012): 17, figs 7, 8A-E gave a long list of citations and synonymy for Leptosynapta inhaerens. To this list we can add:

(KoeHler, 1927): 270, pl XV, Fig 21; (TORTONESE, 1965): 104, Fig. 45; (PÉREZRUZAFA \& LOPEZ-IBOR, 1988): 357; (HAYWARD \& RYLAND, 1990) vol. 2: 871, Fig. 15-14; (PÉreZ-RuZAFA et al., 1992): 176, Fig. 2F; (Madsen \& Hansen, 1994): 102, Figs 3B, C,

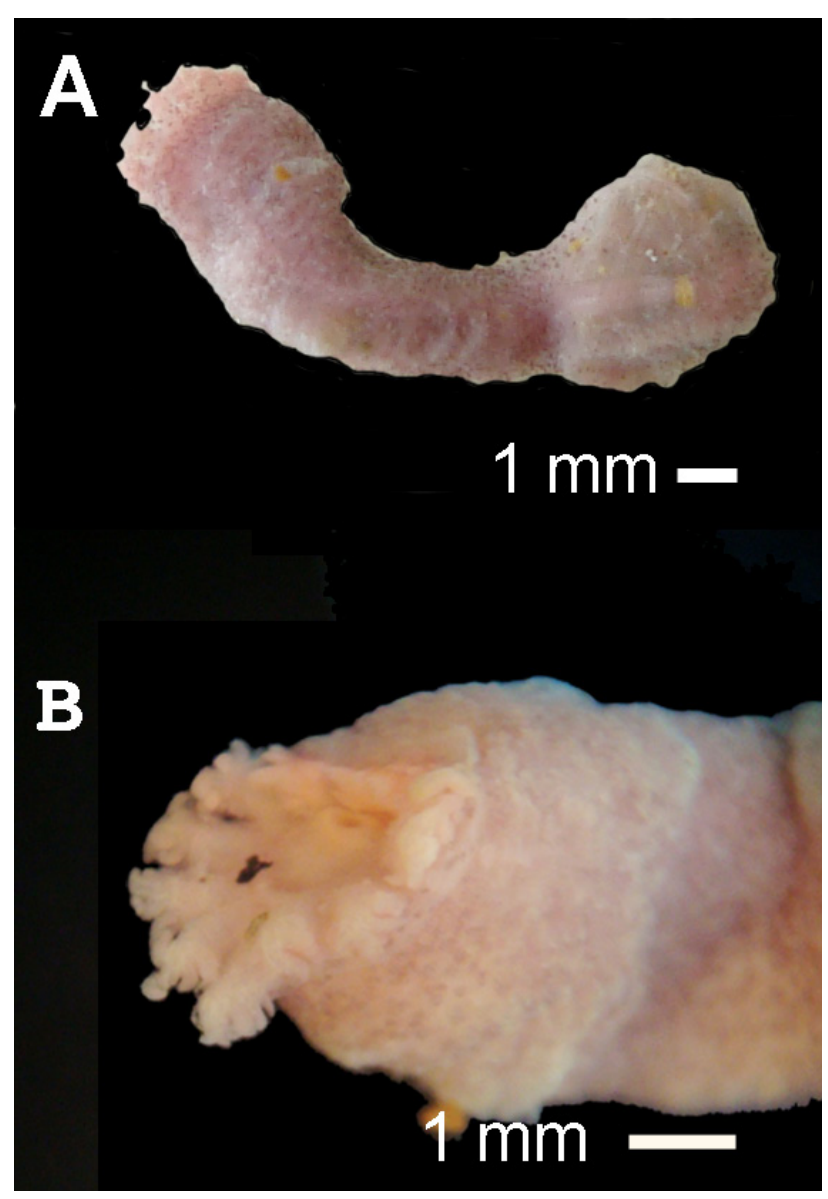

Fig. 1. - Leptosynapta inhaerens (O.F. Müller, 1776). A. Anterior body part. B. Tentacle crown.

64A, 65-66, map 26; (McKenZIE, 1997): 275; (PiCtOn, 1993): 83, Fig. b; (HANSSON, 2001): 350; (SOUTHWARD \& CAMPBELL, 2006): 228, Figs $211 \mathrm{~A}-\mathrm{F}$.

Both specimens appeared to be broken in two. The anterior part of the first specimen, containing the tentacles, was $10.4 \mathrm{~mm}$ long and $3 \mathrm{~mm}$ across (Fig. 1A). The posterior part was contorted, the length estimated at $\pm 7 \mathrm{~mm}$. The posterior part had the same diameter as the anterior part. The specimen had twelve tentacles, which were short with three pairs of digits per tentacle. The terminal digit was single and larger than the laterals (Figs 1B, 2A). The body wall was covered with numerous reddish-brown dots. To preserve integrity of the specimen, no dissection was performed. Consequently, no information on internal anatomy (e.g., calcareous ring) is available. 


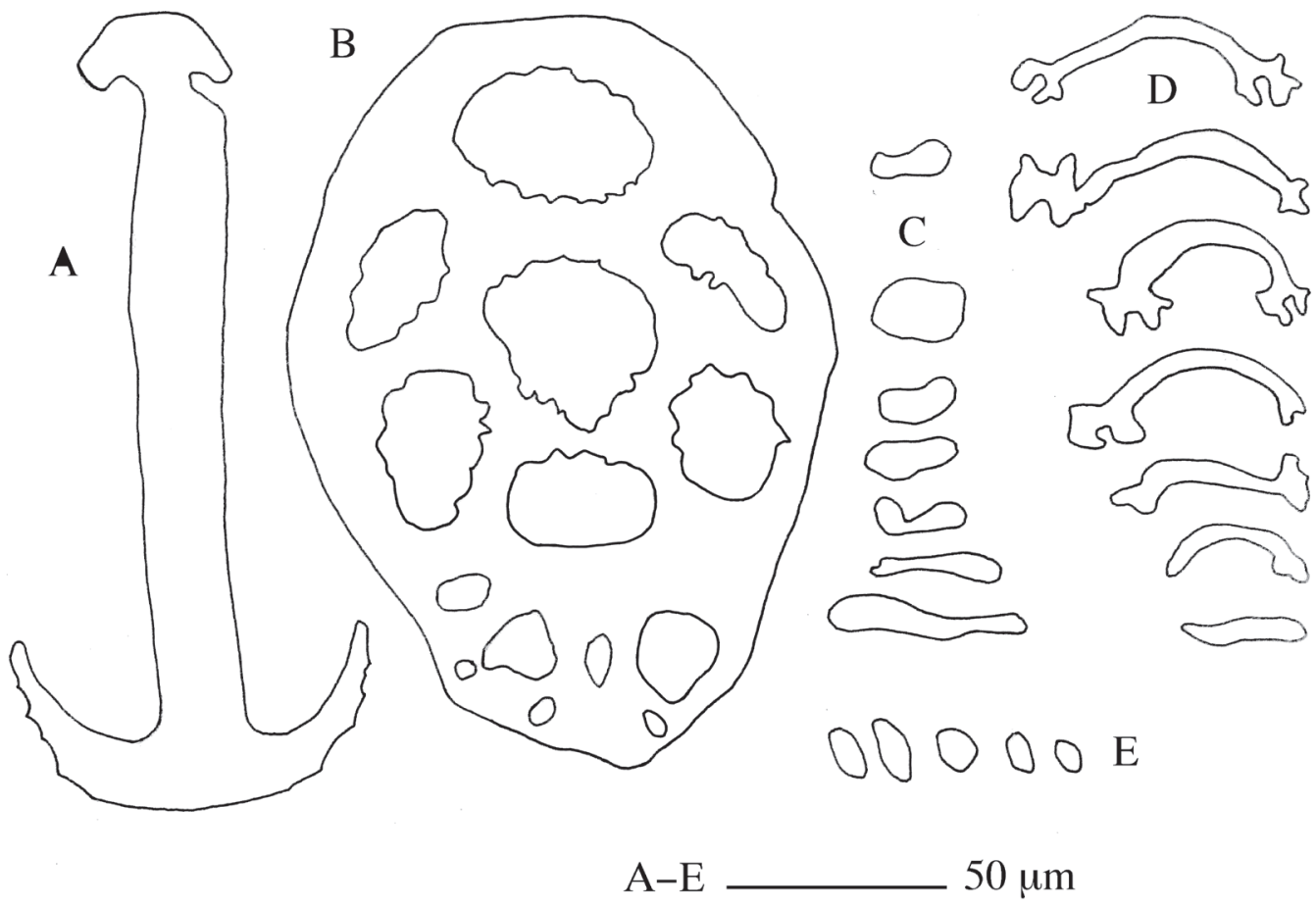

Fig. 2. - Leptosynapta inhaerens (O.F. Müller, 1776). A. Anchor. B. Anchor plate. C. Grains of longitudinal muscles. D. Tentacle rods. E. Tentacle grains.

The ossicles of the body wall comprised anchors and anchor plates. Anchors were 180$220 \mu \mathrm{m}$ long and 80-100 $\mu \mathrm{m}$ wide with 3-4 teeth on arms and a smooth apex (Fig. 2A). Anchor plates were $130-160 \mu \mathrm{m}$ long and $100-170 \mu \mathrm{m}$ wide. The edge of the anchor plates was smooth; the anterior side perforated by seven dentate holes. The posterior side was perforated by 5-8 smooth holes (Fig. 2B). Ossicle variations (mainly the number of holes in the posterior part of the anchor plates) occur within one specimen.

The specimen had longitudinal muscles with grains, 25-50 $\mu \mathrm{m}$ long (Fig. 2C). The tentacles had small smooth curved rods 30-70 $\mu \mathrm{m}$ long (Fig. 2D) and a few grains 15-20 $\mu \mathrm{m}$ long (Fig. 2E).

The second specimen measured $50 \mathrm{~mm}$ long and $2 \mathrm{~mm}$ across (pers. comm. F. KERCKHOF). The identification was based on examination of the anchors and anchor plates.

Leptosynapta inhaerens is a highly variable species (e.g., number of digits (3-10 pairs) per tentacle, number of sense cups (2-14) per tentacle, number of holes (6-14) in the posterior part of anchor plates); already 12 synonyms were mentioned by CLARK (1907). Ossicles vary according to the size of the specimen and to the locality (CLARK 1907: 88-89; MADSEN \& HANSEN, 1994: fig. 66). As a consequence, this species is often confused with Leptosynapta bergensis (Oestergren, 1905) and Leptosynapta tenuis (Ayres, 1851) (MADSEN \& HANSEN, 1994; SOUTHWARD \& CAMPBELL, 2006).

Using the following dichotomous key, separation can be made between the above described species (for illustrations of O-ring ossicles see HEDING (1928): figs 22-40).

\section{Key to the species L. minuta, L. inhaerens,} L. tenuis and $L$. bergensis

1. Ten tentacles without digits L. minuta

- Twelve tentacles with digits .2

2. O-ring ossicles absent in longitudinal muscles .L. inhaerens 
- O-ring ossicles present in the longitudinal muscles .3

3. Rods of tentacles around $30 \mu \mathrm{m}$ long with end faintly enlarged L. tenuis

- Rods of tentacles around $45 \mu \mathrm{m}$ long with enlarged and branched ends ......L. bergensis

\section{HABITAT CHARACTERISTICS}

Sample depth from the Buiten Ratel ranged between 15 and 20 meters. Water temperature and salinity were $15.9{ }^{\circ} \mathrm{C}$ and 34.7 (PSU), respectively. The sediment could be characterised as medium sand, with a median grain size of $265 \mu \mathrm{m}$. The dominant sand fraction (48\%) was medium sand $(250-500 \mu \mathrm{m})$, followed by the fine sand fraction $(125-250 \mu \mathrm{m})(41 \%)$. The coarse fraction $(>1600 \mu \mathrm{m})$ was limited to $7 \%$ of the total mass.

The sampling area was situated in a sand and gravel exploitation zone (Zone 2c) (see Map 1). Intensive extraction activities since 2006 have

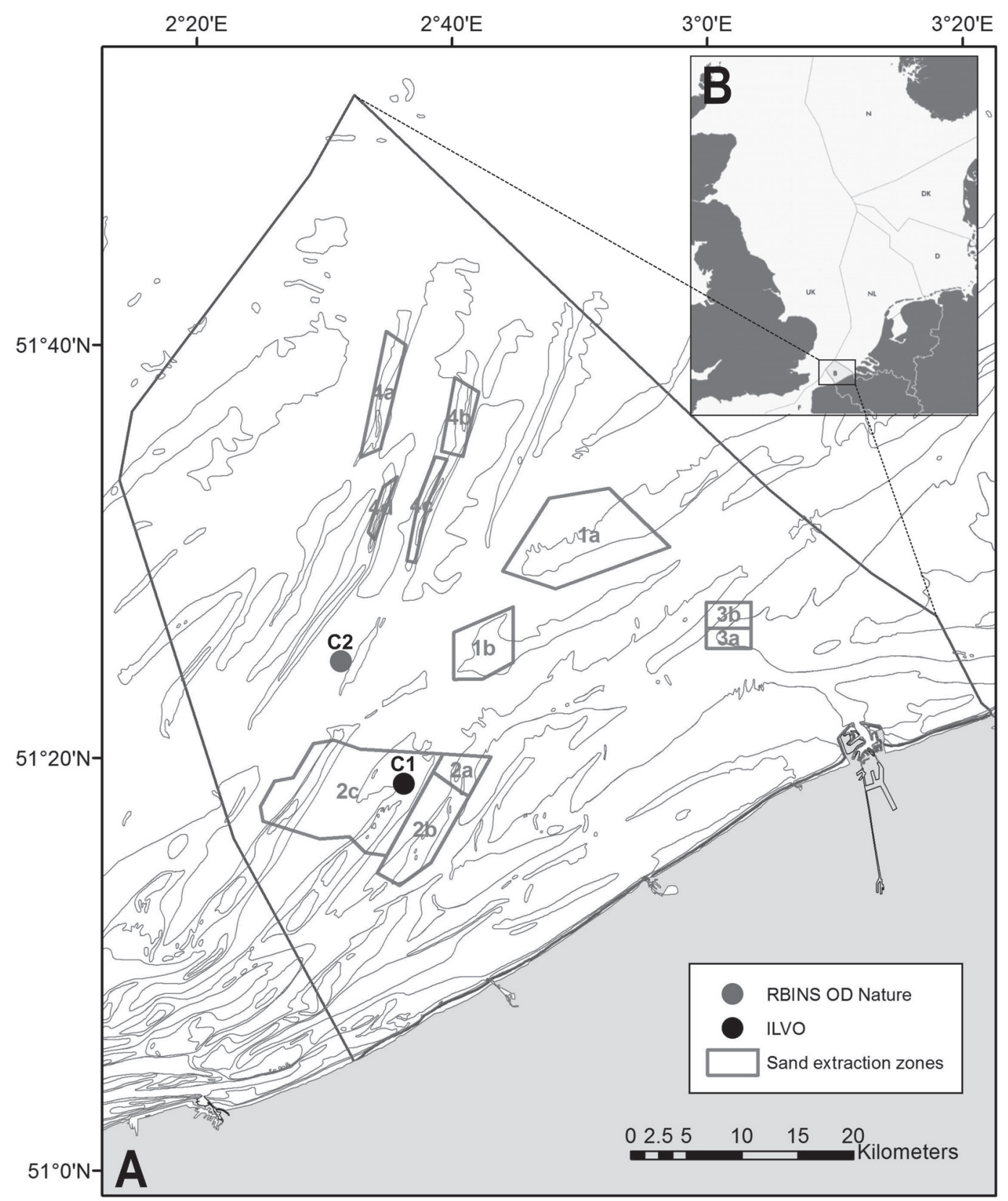

Map 1. - Location of the VAN VEEN grab sample. A. Belgian waters. C1. BRN 10 (located in a zone of high aggregate extraction activities). C2. Location of the Hamon grab sample. 
resulted in the formation of a depression near the sampling area (DE BACKER et al., 2011).

The second specimen was encountered in a mixed sediment type (muddy sand containing a considerable amount of shell debris, and also small cobbles and stones (pers. comm. F. KERCKHOF).

\section{DISTRIBUTION}

Type locality: Southern Norway. Leptosynapta inhaerens is a widespread species mentioned in numerous publications. It has been recorded from the North Sea to northern Norway, all around England, the Atlantic coast of Denmark, Germany, France, Spain, Portugal, the Canary Islands, the Mediterranean coast of Spain, France, Italy, the Adriatic Sea (Greece), the Black Sea, Israel, Korea, Japan and China (see Map 2). This map is mainly based on the work of KoEHLER (1927), PÉREZ-RuZAFA \& LOPEZIBOR (1988), MADSEN \& HANSEN (1994) and SoOK SHIN (2012). However, the presence of
L. inhaerens in Korea, Japan and China (SOOK SHIN, 2012) is still uncertain, because all the specimens studied had O-ring ossicles in the longitudinal muscles (OGURO, 1961; YI, 1985; SoOK SHIN, 2012). These ossicles appear to be absent in L. inhaerens from the North Atlantic and Mediterranean Sea (CLARK, 1907; BUSH, 1918; HEDING, 1928; HAYWARD \& RYLAND, 1990; PÉREZ-RUZAFA et al., 1992; MADSEN \& HANSEN, 1994; SOUTHWARD \& CAMPBELL, 2006). Based on these differences it is likely that the so-called $L$. inhaerens specimens from the Asiatic populations are in fact different species.

L. inhaerens has also been mentioned from Massachusetts (CLARK, 1907), but according to MoRTENSEN (1927) and HEDING (1928) the American specimens are a different species. Leptosynapta inhaerens was also mentioned as being present in the Red Sea (Kosseir, Egypt) and the Congo (LAMPERT, 1885), but these records are not fully confirmed yet (SAMYN, 2003).

Considering the above it is probably unwise to regard $L$. inhaerens as a cosmopolitan

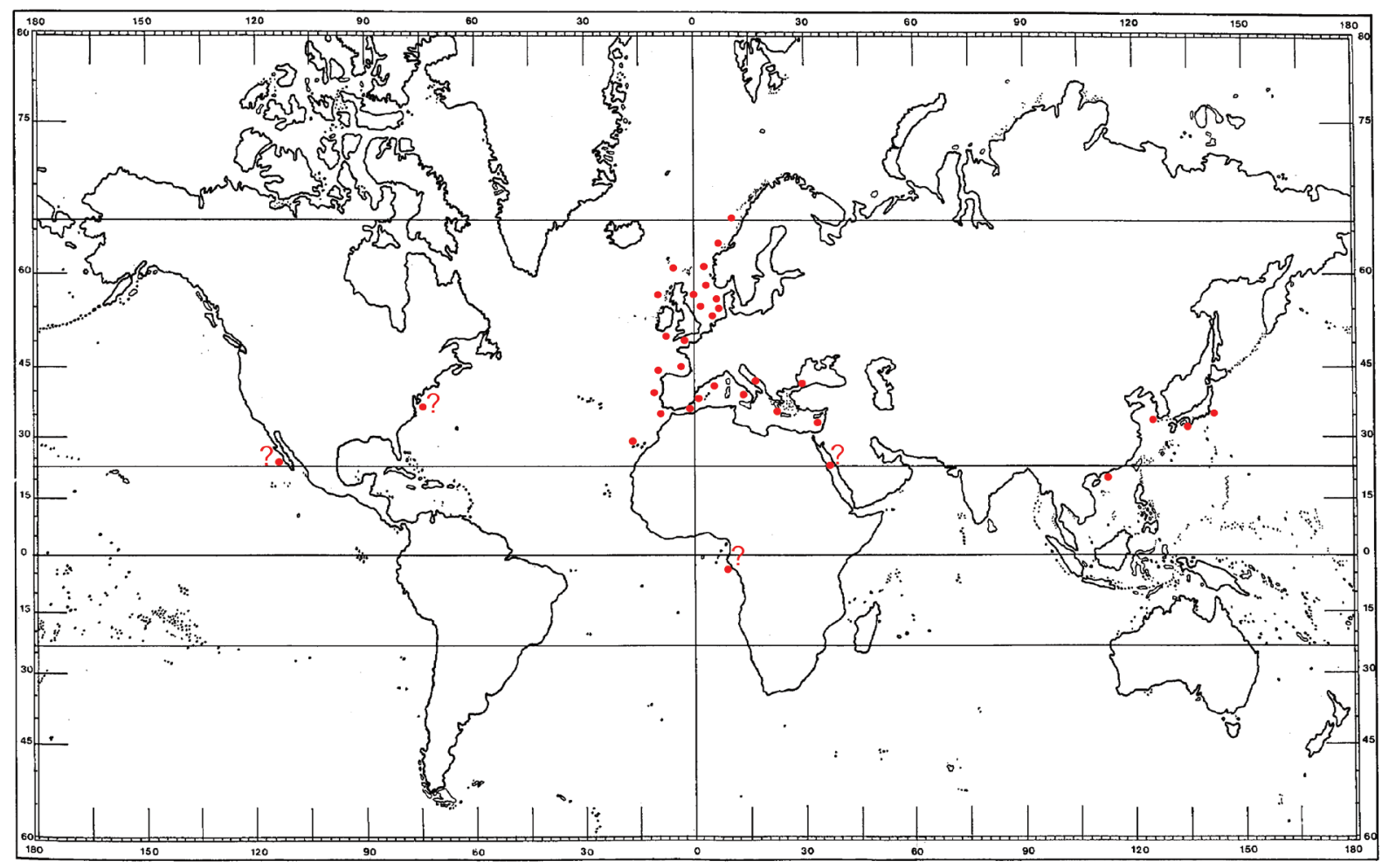

Map 2. - World distribution map of Leptosynapta inhaerens. Dots with a question mark are doubtful. 
species. However there is sufficient evidence confirming its presence in the North Atlantic and Mediterranean Sea.

\section{DISCUSSION}

For Belgian waters, L. inhaerens is newly recorded and is the second known apodid species in this area. These recent observations may even suggest a possible connection between the existing populations of the English Channel and the Southern Bight of the North Sea. Adults leptosynaptids are usually considered to be exclusively bottom-dwelling forms, but COSTELLO (1946) observed young ones (sizes from 30 to $50 \mathrm{~mm}$ ) to be floating near the surface of the water. In case of disturbance they stop their swimming movements, contract their bodies and sink slowly toward the bottom.

ILVO and UG researchers VANDEPITTE et al. (2010), CATTRIJSSE \& VINCX (2001) and DEGRAER et al. (2008) have collected numerous Van Veen samples in the vicinity of, and on to the Buiten Ratel sandbank since 1970. Up till now this is the first registered specimen of $L$. inhaerens. The southern North Sea, with its sandy bottoms and shallow waters $(0-50 \mathrm{~m})$, is expected to be favourable to L. inhaerens (KOEHLER, 1927; Mortensen, 1927; MAdSEN \& HANSEN, 1994). However, according to MADSEN \& HANSEN (1994) and MCKENZIE (1997) the species is supposed to be absent from the southern North Sea, whereas it appears to be an abundant species along the British Isles (MORTENSEN, 1927; SOUTHWARD \& CAMPBELL, 2006). The unexpected rarity of $L$. inhaerens in Belgian marine waters could be related to the grain size distribution and aggregate extraction. Aggregate extraction can disturb the U-shape burrow in which the animal lives. Since 2006, considerable quantities of sand have been systematically extracted from the Buiten Ratel sandbank area (DE BACKER et al., 2011). However, these authors also noted a higher benthic diversity within the Buiten Ratel impact zone, and related this to an overall change in the physical environment (i.e., changes in the sandbank morphology) and the presence of finer sediments, which attracted several new species to the area. Similarly, the disturbed sediments probably also attracted this newly recorded apodid holothuroid species. The recent encounter of another apodid species in the Hinder sandbank area proves that $L$. inhaerens is clearly present in the Belgian marine waters. It remains unclear why the species was never found in the past. Is it because it always appears in very low abundances, minimising a possible catch? Or could its appearance be attributed to a lack of appropriate sampling (in other words, is the Van Veen grab the best collecting gear for small, fragile sea cucumbers)? Maybe future monitoring of both areas could answer these questions?

\section{ACKNOWLEDGEMENTS}

It is our pleasure to thank Dr. Y Samyn (RBINS) for improving the first draft of the paper and for his help with the distribution map. We also thank Mr. A. Van Haelen (RBINS) for preparing figures 1A-B. We thank the crew of the research vessel A962 Belgica for their help during the sampling campaign. Also thanks to J. Vanacker for the analysis of the sediment samples and Dr. A. De Backer (both ILVO) for plotting the geographical map of the sampled area.

\section{REFERENCES}

BARrois Th (1882). Catalogue des Crustaces podophthalmaires et des Echinodermes recueillis à Concarneau. Lille $68 \mathrm{pp}$.

BECHER S (1906). Eine brutpflegende Synaptide der Nordsee. Zoologischer Anzeiger, 30:505-509, figs 1-3.

BRANDT JF (1835). Echinodermata ordo Holothurina: 42-62. In: Prodromus Descriptionis Animalium ab H. Mertensio in Orbis Terrarum Circumnavigatione Observatorum, Fasc. I:75 pp. Petropoli.

BURMEISTER H (1837). Handbuch der Naturgeschichte. Zweite Abteilung Zoologie, Berlin, I-XII, 369-858.

BUSH M (1918). Key to the Echinoderms of Friday 
Harbor. Washington Publications of Puget Sound Biological Station, volume 2 (88):17-48.

CATTRIJSSE A \& VINCX M (2001). Biodiversity of the benthos and the avifauna of the Belgian costal waters. Federal Office for Scientific Technical and Cultural Affairs, $48 \mathrm{pp}$.

Clark HL (1907). The Apodous Holothurians: A Monograph of the Synaptidae and Molpadiidae, including a Report on the Representatives of these Families in the Collections of the United States National Museum. Smithsonian Contributions of Knowledge, 35 (1723):1-231+ 13 pls.

Costello DP (1946). The swimming of Leptosynapta. Biological Bulletin, 90(2):93-96.

DÜBEN VON MW \& KOREN J (1844). Om Holothuriernas Hudskelett. Kungliga Svenska Vetenskapsakademiens Handlingar, 1844:211228.

De Backer A, Van Hoey G, Wittoeck J \& Hostens K (2011). Biological monitoring: Impact of past and present intensive dredging. In: Study day: Marine aggregate extraction: needs, guidelines and future prospects:47-63.

Degraer S, WittoecK J, ApPeltans W, CoOREMAN $\mathrm{K}$, Deprez T, Hillewaert H, Hostens K, Van Den Berghe E, Mees J \& VincX M (2008). L'atlas du macrobenthos de la partie Belge de la mer du Nord. 163 pp.

DEICHMANN E (1944). Urodemas bifurcatum, a new holothurian from South Africa, with a revision of the genus Urodemas Selenka. Annals Magazine Natural History, 11th Series, 11:731-737.

FORBES E \& GOODSIR J (1839). Notice of zoological researches in Orkney and Shetland during the month of June 1839. The athenaeum, 618:647.

GUNNERUS JE (1767). Beskrifning på trenne Norrska Sjö-Kråk, Sjö-Pungar kallade. Kungliga Svenska Vetenskapsakademiens Handlingar, 28:114-124.

HANSSON HG (2001). Echinodermata. In: COSTELLO MJ et al. (ed.), European register of marine species: a check-list of the marine species in Europe and a bibliography of guides to their identification. Collection Patrimoines Naturels 50:336-351.

HAYWARD PJ \& RYLAND JS (eds) (1990). The marine fauna of the British Isles and North-West Europe: 2. Molluscs to chordates. Clarendon Press, Oxford:xvi, 628-996.

HEDING SG (1928). Paper from Dr. Th. MORTENSEN's Pacific Expedition 1914-1916, 46 Synaptidae. Videnskabelige Meddelelser fra Dansk naturhistorisk Forening i Kobenhavn, 86:105323, figs 1-89, pl 2-3.

KOELHER R (1927). Les Echinodermes des mers d'Europe Tome 2. Paris, G. Doin et al. (eds):1$339+$ XVIII pls.

LAMPERT P (1885). Die Seewalzen (Holothuroidea). In: SEMPER C (ed.), Reisen im Archipel der Philippinen. Wiesbaden (2)4(3):1-312, 1 pl.

MADSEN FJ \& HANSEN B (1994). Echinodermata Holothuroidea. Marine Invertebrates of Scandinavia 9. Scandinavian University Press, Norway: 143.

MASsIN C (1988). Note sur deux holothuries nouvelles pour la faune belge. Bulletin de l'Institut Royal des Sciences Naturelles de Belgique, Biologie, 58:71-74.

MASSIN C \& DERIDDER C (1989). Les échinodermes de Belgique. In: WOUTERS K \& BAERT L (eds), Invertebraten van België - Invertébrés de Belgique: Verhandelingen van het Symposium "Invertebraten van België" = Comptes rendus du Symposium "Invertébrés de Belgique" = Proceedings of the Symposium "Invertebrates of Belgium". Brussel, 25-26 november 1988. Koninklijk Belgisch Instituut voor Natuurwetenschappen, Brussel:395-402.

Massin C, Appeltans W, Van Hoey, G, VincX M \& DEgRAER, S (2005). Leptosynapta minuta (Becher, 1906) (Echinodermata, Holothuroidea) a new record for Belgian marine waters. Belgian Journal of Zoology, 135(1):83-86.

MCKENZIE JD (1997). Echinodermata. In: HowsON CM \& PICTON BE (eds), The species directory of the marine fauna and flora of the British Isles and surrounding seas. The Ulster Museum Publication, Belfast, UK, 276:287-295.

MORTENSENTh (1927). Handbook of the echinoderms of the British Isles. Oxford University Press, London:viii +471 .

MÜLler OF (1776). Zoologica Danicae Prodromus seu Animalium Daniae et Norvegiae indigenarum characters, nomine, et synonyma imprimis popularium. Havniae XXXII, 274 pp.

OGuRo C (1961). Occurrence in Asamushi of the apodous holothurian, Leptosynapta inhaerens. Bulletin of the Marine Biological Station of Asamushi, Tohoku University, Vol. 10 (3).

PAWSON D (1967). Protankyra grayi new species and Labidoplax buskii (MacIntosh) from off North Carolina (Holothuroidea, Synaptidae). 
Proceedings of the Biological Society of Washington, 80:151-156.

PÉREZ-RUZAFA A \& LOPEZ-IBOR A (1988). Echinoderm fauna from the south-western Mediterranean. Biogeographic relationships. In: BURKE RD, MLAdENOV PV, LAMBERT P \& PARSLEy RL (eds), Echinoderm Biology:355-362. Balkema, Rotterdam.

PÉREZ-RuZAFA A, MARCos C \& BALlado JJ (1992). Holoturias (Echinodermata: Holothuroidea) de las islas Canarias, II. Ordenes Dendrochirotida, Elasipodida, Apodida y Molpadida. Revista de la Academia Canaria de Ciencias, IV(3-4):163-185.

PICTON BE (1993). A Field Guide to the Shallowwater Echinoderms of the British Isles. IMMEL Publications, London: 96 pp.

SAMYN Y (2003). Shallow-water Holothuroidea (Echinodermata) from Kenya and Pemba Island, Tanzania. Studies in Afrotropical Zoology, 292:iiv, 1-158.

SAMYN Y, VANDENSPIEGEL D \& MASSIN C (2006). Taxonomie des holothuries des Comores. Abc Taxa 1:130 pp.

SoOK SHIN (2012). Invertebrate Fauna of Korea. Sea cucumbers: Echinodermata: Echinozoa: Holothuroidea, Vol. 32(4):1-127.

SOUTHWARD EC \& CAMPBELL AC (2006). Echinodermes: keys and notes for the identification of British species. Synopses of the British fauna (New Series), 56. Field Studies Council: Shrewsbury.
TORTONESE E (1965). Fauna d'Italia. Echinodermata. Calderini, Bologna: 422.

VANDEPITTE L DeCock W \& MeEs J (eds) (2010). Belgian Register of Marine Species, compiled and validated by the VLIZ Belgian Marine Species Consortium. VLIZ Special Publication, 46. Vlaams Instituut voor de Zee (VLIZ), Oostende, Belgium: 78 pp.

VERRILL AE (1867). Notes on the Radiata in the Museum of Yale College, with descriptions of new genera and species. No. 3. On the geographical distribution of echinoderms of the west coast of America. Transactions Connecticut Academy of Arts and Sciences, 1(2):323-351.

YI SK (1985). Studies of the Holothuroidea in the Coastal Waters of Korea: 1. Synaptidae. Ocean Research, 7(1):1-9.

Received: 13 February 2014

Accepted: 12 November 2014

Branch editor: Tom Artois 